\author{
Oleksandr AMOSHA, \\ Oleksandr LYAKH, \\ Myroslava SOLDAK, \\ Danylo CHEREVATSKYI
}

\title{
INSTITUTIONAL DETERMINANTS OF IMPLEMENTATION OF THE SMART SPECIALISATION CONCEPT: CASE FOR OLD INDUSTRIAL COAL-MINING REGIONS IN UKRAINE
}

\begin{abstract}
The paper considers the special features of applying the concept of smart specialization in the old industrial coal-mining regions to implementing the strategy for future sustainable development of the regions, as well as providing recommendations for ensuring the compliance of the institutional environment in such regions of Ukraine with the principles and organizational requirements for the implementation of this concept. The research is methodologically based on

(C) Oleksandr Amosha, Oleksandr Lyakh, Myroslava Soldak, Danylo Cherevatskyi, 2018.

Amosha Oleksandr, Doctor of Economic Sciences, Professor, Academician, National Academy of Sciences of Ukraine (NASU), director.

Lyakh Oleksandr, Cand. of Economic Sciences, Institute of Industrial Economics, National Academy of Sciences of Ukraine.

Soldak Myroslava, Cand. of Economic Sciences, Institute of Industrial Economics, National Academy of Sciences of Ukraine.

Cherevatskyi Danylo, Candidate of Engineering Sciences, Institute of Industrial Economics, National Academy of Sciences of Ukraine.
\end{abstract}


306 Oleksandr Amosha, Oleksandr Lyakh, Myroslava Soldak, Danylo Cherevatskyi

Institutional determinants of implementation of the smart specialisation concept: case for old industrial coal-mining regions in Ukraine

the theoretical principles of the evolutionary economics, in particular, on the concepts of path dependency, lock-ins, and others. As an initial step towards creating new path development of old industrial coal-mining areas, the paper proposes to forming institutional and organizational foundations for the development of industries built on the principles of circular economy. It can be done by returning waste from coal-mining and coal enrichment into production cycles using innovative technologies. It is proved that in the case of the of smart specialization concept application in the conditions of the old coal-mining regions it should be necessary to take a number of institutional measures, the main ones of which are proposed in the paper.

\section{Key words:}

Old industrial regions, coal-mining, economic restructuring, path dependence, lock-ins, regional innovation system, smart specialization, circular technologies.

JEL: O18, O31, O38, Q32, R11.

"Always look at the bright side of a thing, and if there is no such - rub up dark one until it becomes light».

(Chinese proverb)

\section{Introduction}

Deep technological changes, the emergence of new players in the global markets and amplification of resources constraints as well as higher environmental requirements - all these lead to changes in competitiveness of local business firms, individual industries, the whole areas of economic activity in some regions and worsen their social and economic well-being.One of the key topics in economic and social literature devoted to regional development issues is a question, why some regions cope with a decline in dominant economic sectors and renew the economic growth and social resilience while other ones continue to 
depend on traditional depressed industries and/or on long-term and substantial state support. History of globalization processes' deployment demonstrates the fact that the old industrial regions in many countries are predominantly those areas that reap the negative fruits of deepening these processes. At the same time, examples of targeted economic restructuring of such regions in number of countries show that the curse of their industrial past is not an overpowering obstacle to new development paths. The abilities to adapt, to identify new areas for local resources involvement in economic activity, as well as to exploit the opportunities that arise, based on the correlation of indigenous and global trends, - all this combination can be translated into certain advantages that allow such regions to compete even with more technologically advanced ones. However, in each specific case, such a combination of abilities, resources, trends and opportunities is unique. Therefore, the experience of successful examples of old industrial regions restructuring should be perceived rather as evidence of the need to search for such a combination, as well as a guideline that indicates the approximate directions of this search, but not as a recipe like «one size fits all», which is applied without attention to local institutional and structural contexts.

The most difficult for economic restructuring at least in the institutional and structural aspects are the old industrial coal-mining areas. In all countries where coal has been extract by underground mining method, rather than by open pit one, the issues of the old industrial coalmining regions (OICMR) has worsened. As shown in the paper (Amosha et al., 2017), it is regular case that when any fossil fuel-based energy source ceases to be dominant in the energetic balance, the prices for it are set steadily low. The epoch of coal prevalence has ended in the mid-fifties of the last century, and only institutional shocks (such as the oil embargo of 1973 , or the Chinese economic breakthrough in the early 21 st century) could disrupt this pattern. "Capital eschews no profit, or very small profit, just as Nature was formerly said to abhor a vacuum» (Dunning, 1860, p. 36). Low coal prices with high production costs lead to the collapse of entrepreneurship in the coal mining, while the collapse of entrepreneurship leads to a series of closures of coalmines, and in turn, the closure of mines causes the economic and social degradation of the related territories. "In an uncertain world, it also has to be acknowledged that the adjustments to the supply side of global coal markets could come faster and less smoothly than workers, companies and regions currently expect. If recent experience of global energy markets - whether for electricity, oil, gas, nuclear or renewables - has taught us anything, it is that «structural breaks" in the market environment often occur faster and can be more disruptive than key actors think is possible until they actually occur» (Caldecott et al., 2017, p. 4).

This is confirmed by the following case of the Belitskaya coalmine in the Dobropol'sky district of the Ukrainian Donbass. The private company «DTEKEnergo" leases the state-owned coalmine, and since 2014, the coal extracting has not been performing due to the absence of explored reserves at the enterprise, while the leaser has not funds for exploration. Currently, the mine operates 
308 Oleksandr Amosha, Oleksandr Lyakh, Myroslava Soldak, Danylo Gherevatskyi

Institutional determinants of implementation of the smart specialisation concept: case for old industrial coal-mining regions in Ukraine

in the mode of mine waters pumping. The town of Belitskoye with a population exceeding 10 thousand people found itself in an economic crisis. By the way, the population density in the town of Belitskoye is 4.95 thousand people / square $\mathrm{km}$, almost like in the German Ruhr, which is referred to as typical sample of old industrial territorial entities, although the Dobropol'sky district itself has a population density of 17 people / square $\mathrm{km}$.

When coalmines are closing, in the short term it is not realistic to find thousands of jobs for low-qualified employees because employment opportunities in coal-mining settlements and in the surrounding areas are limited. Similarly, regional economies typically cannot easily compensate large losses of economic activity and tax on business and personal revenues that used to be main sources of local budgets and funding of local public services on the territory, in short order (Spencer et al., 2017, p. 7). For instance, in the Limburg region of the Netherlands the allocation of EU Structural Funds to help rebuild the regional economy only officially ceased in 25 years after the beginning of the transition» (Caldecott et al., 2017, p. 8). There is a regularity: the further the mining settlement from the centre of the agglomeration and the more poorly the region itself, the less chance the settlement has for restoration and development, even in an economically developed country like Great Britain (Salyaev, 2002).

One has to take into account that «coal mining elimination leads to an increase in areas that are of a brownfield nature (this status has real estate, land plots, the reuse of which is complicated by the presence of dangerous substances - clarified by us), and sometimes also blackfields, that are understood as extremely contaminated areas, including post-flotation reservoirs, dangerous and toxic waste landfill, impurity tanks, and soil contaminated with chemicals» (Krzysztofik et al., 2011, p. 219).

In Ukraine, under the laws on the coal mines elimination all environmental and social issues must be solved at the expense of the owner. If the mines are state-owned, it has to be on the state budget. But, as practice shows, the funds allocated for the implementation of projects for the closure of mines are never enough, especially for social and environmental needs. In these conditions, without significant external assistance and purposeful efforts of local communities, the most likely the result of mass shutdown of coal mines will be transformation of old industrial coal-mining regions into abandoned territories (for economic sense) with hard environmental and social circumstances.

There are certain similarities in the nature and severity of the troubles that have occurred in the old industrial regions of different countries, but the old industrial coalmining regions have their own peculiarities. Exceptions are cases where mines are territorially aggregated with metallurgical plants or located in conglomerations of large cities, as in the case of the Ruhr region, where the population density reaches 5 thousand people /square $\mathrm{km}$, and the coalmetallurgical part of the agglomeration has practically merged into a single 
«Ruhr-Stadt» («the City of Ruhr») - a continuous series of production sites and settlements.

Depressed mining regions are not a purely Ukrainian feature. American researcher in the field of anthropology Kathleen Stuart (1996) more than twenty years ago wrote the book, in which she described the situation with the closed mines and surrounding settlements in the West Virginia (Appalachian Coal Basin in the US). Abandoned houses, ruins of overhead buildings, mine waters that came to the surface, emanations of methane, burning dumps, rusty trucks and old refrigerators in the middle of the mine yard.... Of course, this situation does not resemble the European reclaimed territories, thoroughly transformed «from black» to the "green» condition, but it is close to the situation in Ukrainian towns adjacent to the mines that have passed the liquidation stage. Therefore, the old coalmining regions have, in the ironic sense, only one strong side - the «mix» of a certain number of unemployed low-skilled labour force and large areas of contaminated territory with mine dumps. In fact, this is a dark side that needs to be «rubbed» (as the Chinese proverb at the beginning of the paper suggests) in order obtaining something worthwhile.

Under conditions of insufficiently developed institutional framework suitable for a regional development policy in decentralized market economy, as in the case for Ukraine (Savelyev, Kurylyak, 2016, p. 106; Zhalylo, 2018, June, 22), the complexity of the structural situation in the coal-mining regions is compounded by the inadequacy of the institutional basics for the policy strategies on regional and local levels, which are aimed at facilitating the revitalizing of economic growth and ensuring certain social and environmental standards in a region.

In recent years, the concept of a regional strategy for smart specialisation has emerged and is developing in the European Union. This concept is officially recognized and disseminated as a practical tool for ensuring innovation-driven sustainable growth and cohesion in the EU, which combines regional, innovation and industrial policies. In certain aspects, the use of this concept may be useful in order to effectively address the issues of old industrial mining regions revitalization. But it requires introducing of appropriate elements of institutional environment in order to elaborate an effective and technically feasible strategy for smart specialization of declining coalmining regions, especially in the institutionally underdeveloped Ukrainian economy. The main question is what additional elements are needed to introduce in the existent institutional environment in the old industrial coalmining regions which will ensure that it conforms to the smart specializations concept and its implementation in the context of necessary activating of local communities' initiative and possibilities for raising funding from European funds?

The aim of this paper is to identify the peculiarities of application of the concept of smart specialization for formation of economic basics for ensuring the future sustainable development of the old industrial coal-mining regions, as well 
310 Oleksandr Amosha, Oleksandr Lyakh, Myroslava Soldak, Danylo Gherevatskyi

Institutional determinants of implementation of the smart specialisation concept: case for old industrial coal-mining regions in Ukraine

as to assess the compliance of the institutional environment in such regions of Ukraine with the principles and organizational requirements for the implementation of this concept. In so doing, we try to methodologically ground our research in the framework of evolutionary economics and applied in the process of its conducting such concepts as path dependency, regional innovation system and smart specialization. From a methodical point of view, the paper is a conceptual contribution and does not include any empirical evidence.

The paper is organized as follows. The next section gives an overview of the main issues of the old industrial regions revitalization with stress on the coalmining regions' peculiarities. Answers to the research questions are provided by a reviewing the relevant literature and the experience of authors obtained during participating in several coal-mining concerned projects and activities of the Agency of Regional Development «Donbass" in the coal-mining settlements of Donetsk and Luhansk oblasts in Ukraine. The next section is devoted to the consideration of the evolution of the concept of smart specialization and to assess the suitability of institutional environment of the old coalmining regions to the principles and organizational requirements of this concept. Further, recommendations will be given on the formation of the necessary framework institutional conditions for the effective and technically feasible application of the concept of smart specialization in the old coal-mining region. The paper is concluded with consideration of some discussion points related to the research topic and conclusions.

\section{Old industrial regions: weaknesses, main issues and directions of their new path creation}

Old industrial regions (OIRs) are defined here as territories with economies dominated by industrial complexes that have evolved over a period of time but are currently undergoing decline and have a relatively low level of technological development, which leads to the loss of regional competitive advantages (Tödtling \& Trippl, 2004; Glonti, 2008; Zhalylo \& Snihova, 2012).

Typically, the OIRs are associated with economic and social decline, the main reasons for which may be:

1) the deterioration of the qualitative and quantitative characteristics of the resource base (Khadzhynov, 2012);

2) changes on the international markets and competitive positions under the orientation on exports of raw materials, primary metals, and chemicals of the 
basic branches of the economy of regions (Tödtling \& Trippl, 2005; Park, 2009; Zhalylo \& Snihova, 2012; Sobolev, 2015; Shelomentseva et al., 2016);

3) transition in post-socialist countries, including the inconsistency of relevant reforms (Swain \& Mykhnenko, 2007; Koutský et al., 2011; Kilar \& Rachwał, 2014; Kubejko-Polańska, 2015; Snihova, 27 May 2016; Hu \& Hassink, 2017);

4) gap in technological development of regional basic industries (Hodson, 2008; Vyshnevsky \& Dementiev, 2011; Tödtling et al., 2013; Kleibrink et al., 2017; Uskova et al., 2017; Lyashenko \& Pydorycheva, 2018);

5) ecological situation (Vishnevsky, et al., 2011; Selin, 2015);

6) a set of above mentioned reasons (Lyakh, 2007; Glonti, 2008; Snihova, 20 August 2016).

The industrialized countries have faced with necessity of structural modernization of the OIRs in the late 70's - early 80-ies of the last century that has been mainly due to the offshoring of production to countries and regions with cheap labour. By the beginning of the XI century, the problem has been decided one way or another by the efforts of regional and national governments as well as the European Union ones. In some places, the economy of the OIRs has been diversified and has gained new breath. In other regions, resolving the task has been slowed down and the problem has gradually disappeared (as the least in a social dimension) due to migration processes. But with the onset of the Great Recession in 2008, the issue of overcoming the socio-economic consequences of the dependence of a number of regions on the stagnant spheres of economic activity has appeared again in a number of urgent and priority tasks in the political agendas as well as has been arousing in academic publications. Requirements for industries, which are associated with the exacerbation of the environmental situation, in particular the transition to the so-called a zero-carbon production, even more actualized the issues of old industrial regions transformation (Campbell \& Coenen, 2017, p. 11; Sartor, 2017, p. 7).

In Ukraine, the problem of restructuring of OIRs was frozen for a long time. Initially, it was associated with rent-seeking attempts of regional business elites to extend the exploitation of assets of basic industries and resource potential of industrialized areas (Lyakh, 2007b; Swain \& Mykhnenko, 2007; Snigova, 2016). This was due to the fact that the low productivity of the basic industries of the old industrial regions was offset by the cheapness of energy resources, raw materials and labor, as well as low ecological requirements for industrial activity. Subsequently, the situation of the old industrial regions as one of the main suppliers of foreign currency to Ukraine and a certain cohesion of the working class of metallurgical and coal mining enterprises of the regions allowed local elites to withstand the sluggish attempts of the central authorities to restructure the economy of these regions as well as to demand certain preferences that were beneficial to this elite. It was on the one hand, and on the other hand, the central gov- 
312 Oleksandr Amosha, Oleksandr Lyakh, Myroslava Soldak, Danylo Gherevatskyi

Institutional determinants of implementation of the smart specialisation concept: case for old industrial coal-mining regions in Ukraine

ernment did not have sufficient political will and financial resources to make real attempts for the radical restructuring of the OIRs economies. As a result, a specific social capital has accumulated in the Ukraine`s OIRs, which became a favourable ground for the instigation of separatist sentiment in these regions, especially in the Eastern coalmining ones (Zhalylo, 2017, June 9) ${ }^{1}$.

There are many publications in which authors tried to present and analyse the experience of OIRs restructuring in Europe and North America (see, for example: Beauregard et al., 1992; Grabher, 1993; Eckart et al., 2003; Hudson, 2005; Lyakh, 2007a; Hodson, 2008; Trippl, 2009; Birch et al., 2010; Koutský, et al., 2011; Lyashenko et al., 2013). But most of these publications evidences on events and policy measures that have occurred ten or more years ago in other global economic situation and in other national, political, regional, and institutional contexts. In the paper (Birch et al., 2010) highlight diverse experiences among the OIRs been investigated and stress on the role of «different national varieties of capitalism in shaping regional trajectories and the different mechanisms of regional adaptation promoted in the different countries» (p. 35).

In order to understand the changing trajectories of development of economic entities, their groupings by industrial or territorial features from growth to decline and vice versa, one has to rely on evolutionary approaches in economics, especially while investigating the development of individual industrial complexes and regional economies. The evolutionary economics considers the economic development of the region as a dynamic process involving on-going transformation, and although it does not pretend to a complete analogy with deployment of natural processes, but emphasises that the main elements of the regional economic system are historically and socially formed (Hudson, 2005, p. 583). It means that during this process, new firms are emerging within the existing spheres of economic activity at the territory of certain regions, and then during their life cycle, most of these firms, depending on external and internal factors, are experiencing growth or decay before they cease their existence, being absorbed by other firms or eliminated. In a market economy, the overall level of regional socio-economic performance (added value, personal revenues of citizens, local budget etc.) results from aggregated performances of firms located in a specific region.

Firms that form regional industry branches seek to promote their interests based on sound rational decisions and interactions with other firms, institutions and public agencies. They gradually form clusters that adapt to the general insti-

\footnotetext{
${ }^{1}$ By the way, according to some researchers, it was the specific social capital that was accumulated in the former coal mining regions of England and the USA that had a significant impact on the results of the Brexit vote and the election of US President D. Trump (Hassink, 2018 cited Barnes \& Christophers, 2018; Snihova, 2016, August, 20; Zhalylo, 2017, June, 9). There was discontent with the quality of life and nostalgia for the industrial past of the population of these regions.
} 
tutions that determine the economic activity in a given country, as well as create their own institutions operating within the cluster. The results of firms' independent or coordinated within the cluster decisions and the interaction of these firms are manifested in the overall regional economic development. Therefore, the evolution of regional industrial branches and clusters, as well as the forms and methods of interaction of all actors that are concentrated in them, is transformed into the evolutionary development of the region's economy.

As stated by Ron Boschma and Jan Lambooy (1999 a, p.414), evolutionary approach may be useful to describe and explain: 1) the process of localized "collective» learning in a regional context, 2) the adjustment problems that have regions in the face of global uncertainty, and 3) the emerging of new industries in a region as an evolutionary process, in which the focus on spatial factors of increasing returns (that is, agglomeration effects) may result in a regional lock-in due to this specialization.

One of the main in the theory of evolutionary economics in relation to regional development is the concept of path dependency. The concept explains how the set of decisions one could apply for any given circumstance can be limited by the decisions one has made in the past, even though past circumstances may no longer be relevant. As for regions, a path-dependent processes [regional development - clarified by us] or systems [economies of regions] are ones whose outcomes [comparative advantages, competitiveness, sustainability etc.] evolve as consequences of the processes or systems own histories (Martin \& Sunley, 2006).

Another concept proposed by Gernot Grabher is closely related to the path dependency and the evolution of the regional institutional environment. This is the concept of lock-ins, which restrain the necessary processes of restructuring regional economies. The situation in which the blocking effect appears is that regions with a high level of specialization in particular industries, with the appropriate resources, competencies and institutional structures, cannot adequately respond to demands of the changing market. The study of Gernot Gräbher (1993) concerning the Ruhr region in Germany showed that the overspecialization of the local economy in coal mining, the production of primary metals, steel and products of basic chemistry in conjunction with the specific institutional environment that matured over time in these regions (close inter-industries ties, political framework of the main actors' coexistence, their cognitive perception of the challenges for the necessary changes), - all this mixture creates barriers for the regional new path creation. In other words, lock-ins can be considered as ...»thick institutional tissues aiming at preserving existing industrial structures and therefore unnecessarily slowing down industrial restructuring and indirectly hampering the development of indigenous potential and creativity» (Hassink, 2005, p. 522). Mike Hodson (2008) applied a figurative expression, emphasizing that the old industrial regions are clamped between the pressure of the need to be transformed 
314 Oleksandr Amosha, Oleksandr Lyakh, Myroslava Soldak, Danylo Cherevatskyi

Institutional determinants of implementation of the smart specialisation concept: case for old industrial coal-mining regions in Ukraine

and he obduracy of social, cultural and institutional relationships in these regions (p.1057).

Gernot Grabher (1993, pp. 260-264) identifies lock-in as threefold and sets off three types: functional, cognitive, and political.

Functional lock-in. It appears when excessively strong and often hierarchically organized inter-firm communications and networks in stagnant industries hinder the development of alternative connections and reorientation of value chains.

Cognitive lock-in. It occurs when the prevailing worldview among the main actors in the region influences the formation of a "collective opinion» that hampers the creative and unbiased approach to developing the necessary solutions and new ideas.

Political lock-in. The existence of close (and often rent-seeking) relationships between representatives of public authorities and the private sector that are aimed at preserving traditional industrial structures and hampering alternative directions of regional development due to fear of personal or collective losses as a result of the restructuring.

«The initial strengths of the industrial districts of the past - their industrial atmosphere, highly developed and specialized infrastructure, the close inter-firm linkages, and strong political support by regional institutions - turned into heavy obstacles to innovation. Regional development became «locked in» by the very socioeconomic conditions that once made these regions «stand out against the rest». In other words, they fell into the trap of 'rigid specialization' » (Grabher, 1993, p. 256). Based on the above, one can state that not only the behaviour of firms that form regional branches of industry and create clusters, but also the policy of local and regional authorities, and in the broader sense, the institutional environment in which firms and authorities are operating, determine the dynamics of development and the ability of OIR's economies to transform. Existence, high degree of negative influence and stability of the manifestation of path dependence in the form of listed lock-ins can significantly inhibit the transformation of the economy of the OIR or even reduce it to nothing. Although this relationship is not deterministic, it is possible to assume with a high degree of certainty the following (see: Hassink, 2017). If the institutional insensitivity or resilience of restructuring is strong in matured industrial clusters suffering from deindustrialization (that is, there are strong cognitive and political lock-ins), there will be a tendency to maintain existing industrial structures or their modernization based on incremental innovations within existing technologies and production capacities (path adjustment). If cognitive and political lock-ins turn out to be weak, then the institutional resistance to restructuring will be weak, and as a result, there may be more opportunities to create new industries that partially stem from existing industries (path renewal). 
In the paper (Tödtling et al., 2013) authors while investigating the dynamics of new industries and firms emerging in OIRs came to the conclusion that this dynamics in each concrete case is related to the institutional background in a region and characteristics of its respective regional innovation systems. The concept of a regional innovation system (RIS), which is also a key element of the evolutionary economics, emphasizes that innovation and economic growth are stimulated by the interaction between geographically-located business and institutions involved in the production and dissemination of knowledge such as universities and research institutes, technology transfer centres, etc. (Freeman, 1987; Braczyk et al., 1998; Asheim \& Coenen, 2005; Doloreux \& Parto; 2005; Isaksen \& Trippl, 2014; Isaksen et al., 2018).

Exploring the path development of the RIS, Arne Isaksen and Michaela Trippl (2016) identified two types of these systems: «thick» and «thin». Thick RISs are predominantly located in urban areas and include institutions of higher education, research centres and a large industrial sector. They are less susceptible to the influence of the path dependence in their development. While thin RISs have these elements to a lesser extent, they are more likely to be affected by the path dependence. According to the authors, the thick RIS can produce a renewal of the regional path development or even a creation of a radically new path. At the same time, thin RIS can only provide modernization of the path development within the existing industrial structure (Isaksen \& Trippl, 2016, pp. $78-80$ ). Berger and Frey (2017) while examining differences in new industry creation across cities, have shown that new industries mainly emerge in human capital abundant places and cities that specialize in industries that demand similar skills. Clearly, there are extremely thin RIS in the coal mining old industrial regions, as well as the lack of a highly skilled workforce, all these means that there are not enough internal resources for a radical change in the path development in these regions.

Nevertheless, the evidences of successful experience in creating a new development path for OIRs after a deep industrial downturn in Europe and North America confirm the prospect and the ability to make fundamental regional transformations. Such a transformation of existing industrial, institutional, social and technological structures is not an easy and simple process, but it is connected with the issues of creative destruction: when new industrial activities, structures and networks appear, but existing ones have to be radically transformed or destroyed (Boschma \& Lambooy, 1999 b, p. 392; Campbell \& Coenen, 2017, p. 1). 


\section{The concept of smart specialization as a new challenge for policy and the possibilities of its application in the old industrial regions}

Not only in regional sciences has occurred a paradigmatic shift of research methodology from orthodox to evolutionary and institutional approaches as well as multi-scalar thinking. The old paradigm in regional policy also is being shifted by new one during last decade. This paradigm of regional policy centred on topdown decision making by the central government agencies, relying on the template solutions that brought successful results in some regions, that is, acting on the principle of «one size fits all». Thus old paradigm was largely ignoring mixed, integrated and bottom-up approaches as well as place-based one. Tödtling \& Trippl (2005, p. 1204) stressed that «...specific strengths and weaknesses of regions in terms of their industries, knowledge institutions, innovation potential and problems are frequently not sufficiently taken into account. Furthermore, regions are often dealt with in an isolated manner, i.e. the interrelationships with other regions and with higher spatial levels (national, international) are left out of consideration». The ineffectiveness of such a regional policy has becoming evident since the last two decades of last century and especially during the overcoming the consequences of the Great Recession, when in each specific case for the regional issues resolving have needed to take into account the specific conditions of the region and to provide more competence for decision-making for those level of power that were closer to the problem and could better elaborate the necessary measures.

The new paradigm of regional policy is «place-based, multi-level, innovative, and geared to different types of regions» (Vanthillo \& Verhetsel, 2012, p.4). Recently, the concept of smart specialization has occupied important place in the regional policy of European countries as well as in academic literature (see, for instance: Vanthillo \& Verhetsel, 2012; McCann \& Ortega-Argiles, 2014; Pyka \& Janiszewski, 2014; Grillitsch, 2016; Sörvik et al., 2016; Kleibrink et al., 2017; Balland et al., 2018). The role of smart specialisation in current European regional policy is to such the extent that the availability of a national or regional strategy for smart specialization has become a prerequisite for funding of countries or regions of the EU from the Structural Funds.

The smart specialisation concept has been elaborated by a group of academic experts named Knowledge for Growth, which has been created by the European Commission, DG for Technology and Innovation in 2008. The concept has been becoming popular in European countries and recently abroad. So popular that it became an example of «policy running ahead of theory». As it rec- 
ognized by main ideologist of the concept with co-authors (Foray, David \& Hall, 2011, p. 1): «... while smart specialisation seems to be already a policy hit and policy makers show some frenetic engagements towards smart specialisation, the concept is not tight in particular as an academic concept... There is therefore a growing gap between the policy practice and the theory».

Initially, the key idea of smart specialization was that leading innovative regions should specialize in $R \& D$ and pioneer introduction of new generalpurpose technologies (i.e. digital, nano-, bio-, advanced materials, etc.), while regions lagging behind in innovative development have to promote these technologies for application by local firms and start-ups. But since the time the concept has evolved and changed radically. Foray, David \& Hall (2011, p. 5) pointed out: «Smart specialisation must not be associated with a strategy of the simple industrial specialisation of a particular region... smart specialisation is a process addressing the missing or weak relations between R\&D and innovation resources and activities on the one hand and the sectoral structure of the economy on the other. Smart specialisation therefore implies rejecting the principle of a sharp division of labour between knowledge producers and knowledge users. Any region is facing at least some challenges in terms of improving the operational efficiency and product quality of "something» and this is a matter of R\&D, capabilities, innovation, etc.»

What this definition means in official European practice is enshrined in the relevant EU regulation (European Parliament and Council, 2013): «'smart specialisation strategy means the national or regional innovation strategies which set priorities in order to build competitive advantage by developing and matching research and innovation own strengths to business needs in order to address emerging opportunities and market developments in a coherent manner, while avoiding duplication and fragmentation of efforts; a smart specialisation strategy may take the form of, or be included in, a national or regional research and innovation (R\&I) strategic policy framework» (article 2, paragraph 3) ... «smart specialisation strategies shall be developed through involving national or regional managing authorities and stakeholders such as universities and other higher education institutions, industry and social partners in an entrepreneurial discovery process» (Annex I, paragraph 4.3, subparagraph 2).

From this definition it can be seen that smart specialization strategies are closely related to the development of regional innovation systems that are able to independently produce new knowledge to translate them into innovations in the regional economy, or to attract external sources of knowledge for innovative development of the region. Trippl and Otto (2009) has identified, more specialized the regional innovation system a region has, a weaker performance with respect to incremental change and diversification but high performance regarding radical change in an established industry it demonstrates. Nevertheless, the shortages of less specialized RIS regarding ability to support radical change of path development can be compensate by applying of exogenous sources of proper knowl- 
318 Oleksandr Amosha, Oleksandr Lyakh, Myroslava Soldak, Danylo Cherevatskyi

Institutional determinants of implementation of the smart specialisation concept: case for old industrial coal-mining regions in Ukraine

edge. The role of exogenous knowledge as sources of new path development has been investigated by Trippl et al. (2017). They argue that different RISs vary substantially in their needs for exogenous sources of knowledge as well as in their capacities to use knowledge generated elsewhere. A region with weak RIS but oriented on attract and absorb non-local knowledge can use this system for accelerating of new regional path development.

Coenen et al. (2015) show that introduction of radical emergent technology is necessary policy direction for new regional path development, but not sufficient. They argue that to avoid a singular focus on technology-push, policy should pay more attention to complementary experimentation processes in relation to demand-side characteristics, firm strategies and business models as well as regulatory aspects. Moreover, coordination between regional innovation policy and adjacent domains and levels of policy-making is needed as some of the most pressing obstacles for renewal of an old industrial region are not specific to the region but instead to the industry at large.

In general terms, the smart specialization (now its full name «Research and Innovation Strategies for Smart Specialization» - RIS3) is a strategic approach to developing a policy of maximizing the region's innovative potential, whether it is economically strong or weak a region and whether it is related to high-tech or low-tech innovations. The process of policy measures elaborating in the frame of RIS3 incorporates elements of both horizontal and vertical policies, that will result in identifying and selecting priority areas (economic activities, technologies, and infrastructures) for targeted support of innovative development of specific regions and countries.

Such an approach is certainly justified, but it does not deny the necessity and effectiveness of local communities' initiatives. As Elinor Ostrom (1990) has shown, irrigation systems created and supported by peasants themselves, primitive structures made of logs, stones and clay can give better results in terms of system stability and socio-economic parameters than the newest reinforced concrete structures built under the projects of professional engineering companies for money from state budget or international donor organizations. The importance of community involvement onto strategic activity with regard to Ukrainian realities, is also stressed by (Zhalylo, 2018): "Strengthening the ability of regional communities to effectively address a significant part of the issues of territorial development increases the inclusiveness of local economies (involvement of all community members in the formation and obtaining of results, as well as increasing their sense of responsibility for this result). In turn, this strengthens the cohesion of the community and forms the consolidated interests of the territories».

Essential opportunities for changing the social and economic situation in the Ukrainian coal-mining OIRs, in our opinion, can ensure the implementation of the smart specialisation approach. It is reasonable to consider the circular economy as an affordable means of reviving the coal-mining OIRs, which receives a 
new impulse with a large-scale implementation of complex programs and individual projects within the so-called «Industry 4.0 ». "Coal sludge is not a problem, it is a raw material.» This motto of the German firm "Hölter" could become the keynote of the smart specialization for the coal-mining OIRs, regardless, whether it is in the Donbas, or the Lviv-Volynsky Coal Basin in Ukraine or in the mining towns of West Virginia in USA, or elsewhere having post-coalmining territories.

Accumulated mass of waste from previous mining activities worsen the environment, but in some cases they are resources for economically advantageous recycling. Even mine water is a powerful economic resource. It has been stressed at the 13th International Congress with the promising title «Mine Water and Circular Economy - A Green Congress» held under the auspices of the Association of Mine Waters in Finland last year (Menéndez et al., 2017, p.13).

The off-balance sludge (flotation waste) formed during the wet separation of coal usually requires the use of sludge recorders (tailings). In Ukraine, according to the Institute of Coal Energy Technologies of the National Academy of Sciences of Ukraine, more than 190 million tons of coal-containing materials have been accumulated in them (Dunaevskaya, 2012).

Differences in approaches to the treatment with mining waste in Europe and in Ukraine prompted the officials of the European Commission to introduce into the Agreement on the Association of Ukraine and the EU the requirement that the subsequent restructuring process should cover all stages of coal production: from mining and enrichment to processing and recycling (Article 339 Section V, Chapter 1).

As an example of the European attitude to the environment, the activity of the special economic zone Katowice, established near the Polish town of Sosnowiec in Silesia, use to be cited. After the shutdown of the old coal mines and related industries enterprises, the return of post-industrial territories to economic activity became a priority there. Of the 27 large facilities has been built, 21 of them are located in cleaned areas, which previously contaminated with waste from mines and washeries. The number of people employed at these facilities is about 6 thousand people (Krzysztofik et al., 2011, p. 219-221). But the economic zone «Katowice» cannot be a model for suggested above a strategy of smart specialization focused on the circular economy, because this zone has not been designed to installation for the useful processing of any coal waste and their recycle.

Unlike the Polish approach to the development of post-mining areas, the project presented at the 2nd International Clean Technology Forum ECOSMART-2012 suggested the start-up for recycling waste of coal enrichment at the Svyato-Varvarinskaya concentrator in the suburb of Krasnoarmeysk (nowadays Pokrovsk) in 2014. Due to military operations in the Donbass the situation has changed, but the project has not lost its relevance. The installed capacity of the proposed electric generation station is $45 \mathrm{MW}$, while supplying to 
consumers 360 million $\mathrm{kWh}$ of electricity per year and producing 67 million ceramic building blocks weighing $3 \mathrm{~kg}$ each ${ }^{2}$. The project may establish the sound foundations for successful economic development of the post coal-mining area.

The German project to turn the «Prosper-Haniel» mine into a pumped storage power plant in the Ruhr Area has led to an increase the attractiveness of this old industrial region due to possibility of using the mines as energy storage (power hubs). Under the project, a pumped energy storage system could generate 200 megawatts of power, enough for almost half a million homes ${ }^{3}$. Hydroaccumulating power stations on the basis of mines can effectively solve not only energy and economic tasks, but also a wide range of social issues.

Electricity hubs in the old industrial regions of Ukraine and Poland could become significant for both countries as well as European energetic, as stated in the report, which was presented at the Polish Sejm at a special symposium on energy issues in October 2017 (Amosha, Cherevatsky, Payonk). Pumped storage power plants on the basis coal mines are also the embodiment of the circular economy, because the mine water used in their work refers to production waste typical of coal mining activities. Some more detailed proposals on the deployment of recycling business in the former coal-mining areas are given in the works (Cherevatsky \& Soldak, 2016; Novak, Soldak, \& Cherevatsky, 2016).

\section{Recommendation and topics for discussion}

In essence, the smart specialization strategies for the Ukrainian coalmining regions should be the strategies of communities' survival after ceasing intensive mining activities in the regions. For these regions, as the initial step in changing the path development may be considered the smart specialisation strategies, which theoretical basis is another concept of an evolutionary economy, the so-called related varieties (see, Frenken, et al., 2007; Asheim, Boschma, \& Cooke, 2011; Balland et al., 2018). This concept suggests that a change in the development path may not start with radical transformations in technologies, business organization patterns, composition and quality of resources used, including labour. Specialisation and related variety capture industries with knowledge that is similar enough to allow for interactive learning and knowledge transfer, and thus innovation (Grillitsch et al., 2018, p. 261).

\footnotetext{
2 Environmental projects of Donetsksteel Group and Innotech Company, 2013. Retrieved from: https://www.youtube.com/watch?v=ZjybWILAsA8. Accessed 12 June 2018.

${ }^{3}$ See: In Germany, miners and others prepare for a soft exit from hard coal. PRI's The World. December 11, 2017. Retrieved from: https://www.pri.org/stories/2017-1211/germany-miners-and-others-prepare-soft-exit-hard-coal. Accessed 20 June 2018.
} 
At the beginning stage of smart specialisation implementing it may be use of technologies and business models that have the potential for diversification of the current economic activity, arising as a result of similarity in the knowledge base and qualifications of workers with other industries that are not currently interwoven with the current one neither in the value chain, nor in trade interdependence. For the old coal-mining regions, such related varieties can become circular productions, which are returning coal mining and coal enrichment waste to production cycles by using innovative technologies.

The transition to a circular economy in the old coal-mining regions requires targeted mobilization of local communities' initiatives and substantial external assistance. Therefore, when elaborating the smart specialization strategy for coalmining OIRs, the first priority is to demonstrate the benefits and focus of all stakeholders, both from the local population and the business environment, on the possibility of achieving high welfare indicators as a result of processing of accumulated industrial wastes.

In this case, it is advisable in the territory of coal mining OIRs to create waste-processing business units in the form of social enterprises or energy cooperatives, the experience of creation and functioning of which has been accumulated in the regions and communes of the EU member states (see: Spiesberger et al., 2018). In the equities of these enterprises there must be a certain share belonging to the community, which will allow controlling the activity of these enterprises from the side of the community, and also participate in the distribution of profits. Networks of such social enterprises and energy cooperatives in the regions with the appropriate infrastructure (centres for the circular technologies transfer, training centres, logistics firms, etc.) are able to accelerate the development of this social initiative within the framework of the smart specialization strategies of coal-mining OIRs. In the future, such networks may transform into eco-innovative clusters with appropriate innovation infrastructure. But the last requires a more detailed study of the expediency and justification of the technical feasibility of such a transformation, since it will require the recruiting of outsourced personnel and a substantial retraining of the workforce in the region.

But there are at least two complications that make it difficult to organize economic activities for the processing of coal mining waste. First, the waste in most cases has its owner - the enterprise, the executive bodies of state power, which can prohibit the processing of waste. Thus, in the late 1990s, the Makeevka Research Institute for the Safety of Work in the Mining has developed an innovative technology for extracting rare-earth elements from waste rock dumps. Due to the fact that there was no internal demand for these materials, the implementation of the project required the attraction of significant foreign investment and the establishment of a joint venture for the export of recovered materials. The Cabinet of Ministers of Ukraine gave a negative response to the relevant request and banned any processing and export activities with rare-earth elements because of its «strategic importance». Close to mentioned is next an insti- 
322 Oleksandr Amosha, Oleksandr Lyakh, Myroslava Soldak, Danylo Gherevatskyi

Institutional determinants of implementation of the smart specialisation concept: case for old industrial coal-mining regions in Ukraine

tutional issue that has to be resolved at the national level - to set clear national goals and standards, according to which state agencies, private firms and other stakeholders should act in cases of revitalization of abandoned former industrial buildings and areas, that is, brownfields. The standards should include recommendations for using these brownfields depending on the types of pollution and directions for the further use of the former industrial object (see: Lyakh, \& Soldak, 2018).

The second complication is the need to attract significant funds for the coal- mining community as an investment. The situation of the deficit of investment resources in such communities in Ukraine is complicated by systemic shortcomings in the state management of regional development, in particular, by the lack of instruments of influence on the development of entrepreneurship, the weak involvement of civil society in the implementation of regional development programs.

It will be possible to arrange municipal loans to the likeness of municipal industrial profitable bonds issued in the Anglo-Saxon countries. Such experience began to break through the bureaucratic barriers in Ukraine (see: Davidenko, 2017). However, the issue of such bonds will require solving a number of institutional problems, first of all, the coordination of the relevant provision and obtaining permission from the Ministry of Finance. A real source of attracting external funding to Ukrainian coal-mining regions may be the presenting the smart specialisation strategies of these regions to European RIS3 Platform and applying to the EU funding due to environmental tasks that these strategies aim to decide. And finally, a real source of strategies implementation funding is the State Fund for Regional Development. For the submission of bids for obtaining funding from the Fund, the existence of an environmentally oriented strategy of smart specialization can very much benefit.

\section{Conclusions}

Typical old industrial coalmining regions are symbiosis of monoindustrial clusters of enterprises and surrounding settlements located in territories with a relatively low population density where. The unfavourable geological conditions of coal deposits, high self-production costs and stable low prices for coal cause shrinkage of coal mining and coal mines closure in Ukraine. The old industrial coalmining territories in Ukraine are threatened with complete degradation and transformation into abandoned ones with severe environmental and social situation after the discontinuation of intensive coal mining activities, unless measures to diversify economic activity in these territories are implemented. 
In order to understand the possibilities for changing of trajectories of old industrial coal-mining regions development one has to rely on evolutionary approaches in economics which considers the economic development of the region as a dynamic process involving on-going transformation, and the main elements of the regional economic system as historically and socially formed ones. The main concept of the evolutionary economics theory in relation to regional development is the concept of path dependency, which in its turn determines the concepts of functional, cognitive and political lock-ins. The works of a number of researchers devoted to issues of development, decay and revitalization of the old industrial regions has shown that in order to reduce cognitive and political barriers and to avoid a significant opposition to the restructuring of the region by local institutions and actors, it is first of all necessary to ensure an appropriate institutional environment.

In the mining region's conditions with the institutional environment distorted by the path dependence, almost complete lack of a proper regional innovation system, as well as the presence of predominantly low-skilled labour, the restructuring of economic activity in these regions by encouraging the emergence of fundamentally new branches of economic activities and planting of high-tech industries is not realistic.

For the old coal-mining regions, as the initial step in changing the path development may be considered the strategies, which theoretical basis is another concept of an evolutionary economy, the so-called related varieties. This concept suggests that a change in the path development may not start with radical transformations in technologies, business organization patterns, composition and quality of resources used, including labour. At the beginning it may be use of technologies and business models that have the potential for diversification of the current economic activity, arising as a result of similarity in the knowledge base and qualifications of workers with other industries that are not currently interwoven with the current one neither in the value chain, nor in trade interdependence. For the old coal-mining regions, such related varieties can become circular productions, which are returning coal mining and coal enrichment waste to production cycles by using innovative technologies.

The transition to a circular economy in the old coal-mining regions requires targeted mobilization of local communities' initiatives and substantial external assistance. A real source of attracting external funding to Ukrainian coal-mining regions may be the application of European experience in elaborating of regional smart specialization strategies. In essence, the smart specialization strategy for the coal-mining regions should be a strategy of communities' survival after ceasing intensive mining activities in the regions on the basis of the mentioned circular production technologies. This will provide satisfactory level of the welfare in the community over a period of time necessary to further restructure the region's economy, including on the basis of the modern technologies. The volume of the accumulated waste in the region has to be sufficient for generated revenues that 
324 Oleksandr Amosha, Oleksandr Lyakh, Myroslava Soldak, Danylo Cherevatskyi

Institutional determinants of implementation of the smart specialisation concept: case for old industrial coal-mining regions in Ukraine

allow overcoming poverty and ensuring sustainable development during needed period.

It is also necessary to create information and consultation platforms for smart specialisation in the old industrial coal- mining regions, which will expand the capacity of all stakeholders to work together on investing in brownfields objects in the coal-mining territories, will provide communication channels between potential investors and officials and policy-makers on the regional and local levels, facilitate access to the necessary information, for example, covering land use opportunities and attracting financial resources, and also facilitates the search for creative projects for the restoration of abandoned territories.

To implement the smart specialization strategy elaborated for the old industrial coal-mining regions and aimed at deploying business in these regions engaged in the recycling of coal industry waste, it is necessary to resolve the following institutional issues:

- to provide access of the communities of the respective regions to the coal mining waste and coal enrichment reserves;

- to set clear national goals and standards, according to which state agencies, private firms and other stakeholders should act in cases of revitalization of abandoned former industrial buildings and areas, that is, brownfields;

- to create the necessary mechanisms of state support for investing in projects devoted to deployment of circular production using various forms of financing, including the issuance of local loans.

\section{References}

1. Amosha, A., Cherevatsky, D., Payonk, K. (2017). Energy diversification. Energobiznes, 40, 16-19.

2. Amosha, A.I., Zaloznova, Yu.S., and Cherevatsky, D.Yu. (2017). A coal industry and the hybrid economy. Kiev: Institute of Industrial Economics of NAS of Ukraine, 196 p. [In Russian].

3. Asheim, B.T., Coenen, L. (2005). Knowledge bases and regional innovation systems: Comparing Nordic clusters. Research policy, 34(8), 1173-1190. doi: 10.1016/j.respol.2005.03.013

4. Asheim, B.T., Boschma, R., and Cooke, P. (2011). Constructing regional advantage: Platform policies based on related variety and differentiated knowledge bases. Regional Studies, 45(7), 893-904. doi: $10.1080 / 00343404.2010 .543126$ 
5. Balland, P.-A., Boschma, R., Crespo, J., and Rigby, D.L. (2018). Smart specialization policy in the European Union: relatedness, knowledge complexity and regional diversification. Regional Studies. Retrieved from: https://rsa.tandfonline.com/doi/full/10.1080/00343404.2018.1437900\#.WxfCc-6FOHs. Accessed 20 June 2018. doi: 10.1080/00343404.2018.1437900.

6. Beauregard, R., Lawless, P., and Deitrick, S. (1992). Collaborative strategies for reindustrialization: Sheffield and Pittsburgh. Economic Development Quarterly, 6(4), 418 - 430. doi: 10.1177/089124249200600408.

7. Berger, T., Frey, C. B. (2017). Industrial renewal in the 21st century: Evidence from US cities. Regional Studies, 51(3), 404-413, doi: 10.1080/00343404.2015.1100288.

8. Birch, K., MacKinnon, D., Cumbers, A. (2010) Old industrial regions in Europe: a comparative assessment of economic performance. Regional Studies, 44(1), 35-53. doi: 10.1080/00343400802195147.

9. Boschma, R., Lambooy, J. (1999a). Evolutionary economics and economic geography. Journal of Evolutionary Economics, 9, 411-429. doi: 10.1007/s001910050.

10. Boschma R., Lambooy, J. (1999b). The prospects of an adjustment policy based on collective learning in old industrial regions. GeoJournal, 49(4), 391-399. doi: 10.1023/A:1007144414006.

11. Braczyk, H.-J., Cooke, P., Heidenreich, M. (eds) (1998). Regional Innovation Systems: The Role of Governances in a Globalized World. 2nd Edition. London: UCL Press, $442 \mathrm{p}$.

12. Caldecott, B., Sartor, O., Spencer, T. (2017). Lessons from previous «Coal Transitions». Part of "Coal Transitions: Research and Dialogue on the Future of Coal» Project. High-level Summary for Decision-makers, IDDRI and Climate Strategies. Retrieved from: https://coaltransitions.files.wordpress.com/ 2016/09/coal_synthesisreport_v04.pdf. Accessed 25 June 2018.

13. Campbell, S., Coenen, L. (2017). Transitioning beyond coal: Lessons from the structural renewal of Europe's old industrial regions. CCEP Working Paper No 1709, November 2017. Canberra: The Centre for Climate Economics \& Policy, Crawford School of Public Policy at The Australian National University, $18 \mathrm{p}$.

14. Cherevatsky, D., Soldak, M. (2016, May, 27). From dirt to human: Electricity from waste of coals enrichment. Mirror of the week, No. 1094. Retrieved from: https://dt.ua/energy_market/z-brudu-v-lyudi-elektroenergiya-z-vidhodivzbagachennya-vugillya-_.html. Accessed 25 June 2018. [In Ukrainian].

15. Coenen, L., Moodysson, J., \& Martin, H. (2015). Path renewal in old industrial regions: Possibilities and limitations for regional innovation policy, $R e-$ gional Studies, 49:5,850-865. doi: 10.1080/00343404.2014.979321. 
16. Davidenko E. (2017, June, 02). An investor to himself. Investing locally in infrastructure objects within the community Mirror of the week, No. 1146. Retrieved from: https://dt.ua/business/sam-sobi-investor-investuvannya-miscevimizhitelyami-v-ob-yekti-infrastrukturi-na-terenah-svoyeyi-gromadi-244414_.html. Accessed 25 June 2018. [In Ukrainian].

17. Doloreux, D., Parto, S. (2005). Regional innovation systems: Current discourse and unresolved issues. Technology in Society. 27, 133-153. doi: 10.1016/j.techsoc.2005.01.002.

18. Dunaevskaya, N.I. (25 June 2018). On the issue of the integrated use of slurries, dry coal-mining wastes, high-iron and brown coal in power engineering. Retrieved from: http://esco.co.ua/journal/2012_5/art225.pdf. [In Russian].

19. Dunning, T.J. (1860). Trades' unions and strikes: Their philosophy and intention. London: Published by the author, and sold by M. Harley, No 5, Raquet Court, Fleet Street, E.C., 66 p.

20. Eckart, K., Eckart-Muiller, I., Ehrke, S., \& Krähe, H. with contributions by Mezulánik, J., Veselý, I. (2003). Social, economic and cultural aspects in the dynamic changing process of old industrial regions: Ruhr District (Germany), Upper Silesia (Poland), Ostrava Region (Czech Republic). Münster: Lit Verlag, $368 \mathrm{p}$.

21. European Parliament and Council (2013). Regulation (EU) No 1303/2013 of the European Parliament and of the Council. Official Journal of the European Union, 20 December 2013 (pp. L 347/320-L 347/465). Retrieved from: https://eur-lex.europa.eu/eli/reg/2013/1303/oj. Accessed 07 July 2018. Accessed 22 June 2018.

22. Foray, D., David, P.A., Hall, B.H. (2011). Smart specialization: from academic idea to political instrument, the surprising career of a concept and the difficulties involved in its implementation. MTEI Working Paper, Lausanne, Switzerland, $16 \mathrm{p}$.

23. Freeman, C. (1987). Technology, policy, and economic performance: Lessons from Japan. London / New York: Pinter Pub Ltd., 150 p.

24. Frenken, K., Van Oort, F., Verburg, T. (2007). Related variety, unrelated variety and regional economic growth. Regional Studies, 41(5), 685-697. doi: 10.1080/00343400601120296.

25. Glonti, K.M. (2008). Older industrial regions: Issues and prospects for development. Regionology, 4. Retrieved from: http://regionsar.ru/node/197? page $=0,2$. Accessed 22 June 2018. [In Russian].

26. Grabher, G. (1993). The weakness of strong ties; the lock-in of regional development in the Ruhr area. In G. Grabher (ed.), The embedded firm: On the socioeconomics of industrial networks (pp. 255-277). London / New York: Routledge. 
27. Grabher, G. (1994). The dissembedded regional economy: The transformation of East German industrial complexes into Western enclaves. In: Amin, A. and Thrift, N. (eds.). Globalization, institutions, and regional development in Europe (pp. 177-195). New York: Oxford University Press.

28. Grillitsch, M. (2016). Institutions, smart specialisation dynamics and policy. Environment and Planning C: Government and Policy, 34 (1), 22-37. doi: $10.1177 / 0263774 \times 15614694$

29. Grillitsch M., Asheim, B.T., Trippl, M. (2018). Unrelated knowledge combinations: The unexplored potential for regional industrial path development. Cambridge Journal of Regions Economy and Society 11(2), 7, 257-274. doi: 10.1093/cjres/rsy012.

30. Hassink, R. (2005). How to unlock regional economies from path dependency? From learning region to learning cluster, European Planning Studies, 13(4), 521-535. doi: 10.1080/09654310500107134.

31. Hassink, R. (2010). Locked in decline? On the role of regional lock-ins in old industrial areas. In Boschma, R. and Martin, R. (eds.), Handbook of Evolutionary Economic Geography (pp. 450-468). Cheltenham: Edward Elgar.

32. Hassink, R. (2017). Cluster decline and political lock-ins . In F.Belussi and J. L. Hervás Oliver (eds.) Unfolding Cluster Evolution. London: Routledge, $312 \mathrm{p}$.

33. Hassink, R. (2018). Book review of Barnes, T. J., \& Christophers, B. (2018) Economic geography: a critical introduction. Chichester: John Wiley \& Sons. Zeitschrift für Wirtschaftsgeographie, Published online: May 2018. Retrieved from: https://www.researchgate.net/publication/324441606_Book_review_of_Barnes_T_J_Christophers_B_2018_Economic_geography_a_critica I_introduction_Chichester_John_Wiley_Sons. Accessed 22 June 2018.

34. Hodson, M. (2008). Old industrial regions, technology and innovation: tensions of obduracy and transformation. Environment and Planning A: Economy and Space, 40 (5), 1057-1075. doi: 10.1068/a39103.

35. Hospers, G.-J. (2011). Breaking out from lock-in: regional innovation strategies in the German Ruhrgebeit. In Ordóñez de Pablos, P., Lee, W.B., and Zhao, J. (eds.), Regional Innovation Systems and Sustainable Development: Emerging Technologies (pp. 43-56). Hershey: Information Science Reference. doi: 10.4018/978-1-61692-846-9.ch005.

36. Hospers, G.-J., Benneworth, P. (2012). Innovation in an old industrial region: The case of Twente. International Journal of Learning and Intellectual Capital, 9 (1/2), 6-27. doi: 10.1504/IJLIC.2012.043978.

37. Hu, X., Hassink, R. (2017). New perspectives on restructuring of old industrial areas in China: a critical review and research agenda. Chinese Geographical Science, 27(1), 110-122. doi: 10.1007/s11769-015-0784-8. 
38. Hudson, R. (2005). Rethinking change in old industrial regions: reflecting on the experiences of North East England. Environment and Planning A, 37, 581- 596. doi:10.1068/a36274.

39. Isaksen, A., Trippl, M. (2014). Regional industrial path development in different regional innovation systems: A conceptual analysis. CIRCLE Working Paper in Innovation Studies № WP 2014/17. Centre for Innovation, Research and Competence in the Learning Economy (CIRCLE), Lund University, $18 \mathrm{p.}$

40. Isaksen, A., Trippl, M. (2016). Path development in different regional innovation systems: A conceptual analysis. In M. Parrilli, R. Fitjar, and A. Rodriguez-Pose (eds.) Innovation Drivers and Regional Innovation Strategies. (66-84). New York - London: Routledge.

41. Isaksen A., Martin R., Trippl M. (2018). New avenues for regional innovation systems and policy. In: Isaksen A., Martin R., Trippl M. (eds). New avenues for regional innovation systems - Theoretical advances, empirical cases and policy lessons. (1-19). Cham: Springer. doi: 10.1007/978-3-319-71661-9_1

42. Khadzhynov I. (2012). Old industrial regions of Ukraine: Development tendencies. Theoretical and Practical Aspects of Economics and Intellectual Property, 1(3), 72-77. [In Ukrainian].

43. Kilar, W., Rachwał, T. (2014). Changing role of industry in the economy in the V4 countries - a regional approach. Club of Economics in Miskolc' TMP, 10 (1), 45-54.

44. Kleibrink, A., Larédo, P., Philipp, S. (2017). Promoting innovation in transition countries: A trajectory for smart specialisation, EUR 28638 EN, Brussels: European Union. doi: 10.2760/988830.

45. Koutský, J., Slach, O., Boruta, T. (2011). Restructuring economies of old industrial regions - local tradition, global trends. In The Scale of Globalization. Think Globally, Act Locally, Change Individually in the 21st Century. 5th International Conference on Globalization.Ostrava, Czech Republic, September 8-9, 2011. Ostrava: University of Ostrava, 166-173. Retrieved from: http://conference.osu.eu/globalization/publ2011/166-173_Koutsky-SlachBoruta.pdf. Accessed 22 June 2018.

46. Krzysztofik, R., Runge, J., \& Kantor-Pietraga, I. (2012). Paths of environmental and economic reclamation: The case of post-mining brownfields. Polish Journal of Environmental Studies, 21 (1), 219-223.

47. Kubejko-Polańska, E. (2015). Restructuring problems and the role of the market economy processes in the development of former industrial centers in selected European countries. In Economic development: Processes and tendencies. III International scientific - practical conference. University of applied sciences, Faculty of economics. Vilnius, April 29, 2015. T.1. Vilnius: Vilniaus kolegija, 356-368. 
48. Lyakh, A.V. (2007a). Restructuring of old industrial regions: Foreign experience and possibilities of its application. In Makagon, Yu.V., Khadzhynov, I.V. (eds). Issues of international economic relations developing and foreign investments attracting: a regional aspect (1661-1666). Donetsk: DonNU. [In Russian].

49. Lyakh, A. (2007b). The evolution of the industrial structure in Donetsk region: Macroeconomic, microeconomic and institutional features factors. In A. Swain (ed.), Re-constructing the Post-Soviet Industrial Region: the Donbas in Transition (pp. 78-96). London: Routledge.

50. Lyakh, O.V., Soldak, M.O. (2018). Perspectives of innovative restoration of abandoned industrial sites in Ukraine based on the application of international experience with brownfields treatment. In $\mathrm{O}$. Amosha, $\mathrm{H}$. Jivigol, R. Mishkevich (eds.), Innovative industrial enterprise in the formation of sustainable development (pp. 167-194). Kyiv: National Academy of Sciences of Ukraine, Institute of Industrial Economics. [In Ukrainian].

51. Lyashenko, V. I., Pydorycheva, I. Yu. (2018). Innovative perspectives of the old-developed territories: foreign experience and possibilities of its applying in Ukraine. In O. Amosha, H. Jivigol, and R. Mishkevich (eds.), Innovative industrial enterprise in the formation of sustainable development (pp. 118147). Kyiv: National Academy of Sciences of Ukraine, Institute of Industrial Economics. [In Ukrainian].

52. Lyashenko, V.I., Snegovaya, E.Yu., and Tulkku, Ya.V. (2013). Structural problems of the old industrial regions of European countries: a retrospective and prospects. In Lyashenko, V.I. (ed.). Structural transformations of the old industrial regions of Ukraine (pp. 88-111). Donetsk: National Academy of Sciences of Ukraine, Institute of Industrial Economics. [In Russian].

53. Martin, R., Sunley, P. (2006). Path dependence and regional economic evolution. Journal of Economic Geography, 6(4), 395-437. doi: 10.1093/jeg/lbl012.

54. McCann, P., Ortega-Argiles, R. (2014). Smart specialisation in European regions: Issues of strategy, institutions and implementation. European Journal of Innovation Management, 17 (4), 409 - 427. doi: 10.1108/EJIM-05-20140052.

55. Menéndez J., Loredo, J., Fernandez, M., Galdo, M. (2017). Underground pumped-storage hydro power plants with mine water in abandoned coal mines. Proceedings of the IMWA 13th International Congress. Retrieved from: http://www.imwa.info/docs/imwa_2017/ IMWA2017_Menendez_6.pdf. Accessed 22 June 2018.

56. Novak, I.N., Soldak, M.A., and Cherevatsky, D.Yu. (2016). New Energy Future of the Mining Region. Labour protection, 8, 12-14. [In Ukrainian] 
57. Ostrom, E. (1990). Governing the commons: The evolution of institutions for collective action. Cambridge University Press, $280 \mathrm{p}$.

58. Park, G.-H. (2009). Endogenous growth in entrepreneurial environments: A pathdependent process for competitive regional development, International Journal of Urban Sciences, 13 (1), 42-62. doi: 10.1080/12265934.2009.9693645.

59. Pyka, J., Janiszewski, A. (2014). Smart specialisations in regional innovation ecosystem. Journal of European Economy, 13 (1), 33-51.

60. Rodríguez-Pose, A. (2013). Do institutions matter for regional development? Regional Studies, 47(7), 1034-1047. doi: 10.1080/00343404.2012.748978.

61. Salyaev, A.V. (2002). Life without coal: rebirth or decline. Coal, 3, 63-65. [In Russian].

62. Sartor, O. (2017). Strengthening national coal transitions to raise climate ambition. Issue Brief. Part of the "Coal Transitions: Research and Dialogue on the Future of Coal». Project IDDRI and Climate Strategies. - November 2017. $-12 \mathrm{p}$.

63. Savelyev, Y., Kurylyak, M. (2016). The concept of regional reforms in Ukraine under the NUTS. Journal of European Economy, 15 (1), 89-115.

64. Selin, V.S. (2015). Economics of old industrial regions as a promising area of scientific research. National Interests: Priorities and Security, 41, 58-63. [In Russian].

65. Shelomentseva, V.P, Ifutina, E.A, Shelomentsev P.Yu. (2016). Old-industrial region: the nature of origin, classification, transformation. Bulletin of the University of Turan (Almaty), 2 (70), 49-53. [In Russian].

66. Snihova, O. (2016, May, 27). Old industrial regions of Ukraine: How to get rid of the Stockholm syndrome. Mirror of the week, No.1094. Retrieved from: http://gazeta.dt.ua/macrolevel/staropromislovi-regioni-ukrayini-yakpozbutisya-stokgolmskogo-sindromu-_html. Accessed 25 June 2018. [In Ukrainian].

67. Snihova, O. (2016, August, 20). Brexit: Ghosts of the industrial past and the challenges of reforms for Ukraine. Mirror of the week, No. 1104. Retrieved from: https://dt.ua/macrolevel/brexit-prividi-industrialnogo-minulogo-i-vilnireform-dlya-ukrayini-_.html. Accessed 25 June 2018. [In Ukrainian].

68. Sobolev, A.O. (2015). Foreign experience of innovative development of old industrial regions and possibilities of its applying in Russia. Issues of management, 32, pp. 73-80. [In Russian].

69. Sörvik J., Midtkandal I., Marzocchi C., Uyarra E. (2016). How outwardlooking is smart specialisation - results from a survey on inter-regional collaboration in Smart Specialisation Strategies (RIS3), S3 Policy Brief Series 
No. 16/2016; Luxembourg: Publications Office of the European Union, EUR 27795 EN, doi:10.2791/943671.

70. Spencer, T., Colombier, M., Sartor, O., Garg, A., Tiwari, V., Burton, J., Caetano, T., Green, F., Teng, F., \& Wiseman, J. (2017). The $1.5^{\circ} \mathrm{C}$ target and coal sector transition: At the limits of societal feasibility. Climate Policy, Published online: 04 Dec 2017. doi: 10.1080/14693062.2017.1386540.

71. Spiesberger M., Gomez Prieto, J., Seigneur, I. (2018). Smart specialisation and social innovation: from policy relations to opportunities and challenges. S3 Policy Briefs Series, No. 24/2018. EUR 29230 EN, Luxembourg: Publications Office of the European Union, 30 p. doi: 10.2760/601340.

72. Stuart K. (1996). A space on the side of the road: cultural poetics in an "other» America. Chichester, West Sussex: Princeton University Press, $264 \mathrm{p}$.

73. Swain, A., Mykhnenko, V. (2007). The Ukrainian Donbas in «Transition». In A. Swain (ed.), Re-constructing the Post-Soviet Industrial Region: the Donbas in Transition (pp. 7-46). London: Routledge.

74. Tödtling, F., Trippl, M. (2004). Like phoenix from the ashes? The renewal of clusters in old industrial areas. Urban Studies, 41(5-6), 1175-1195. doi: 10.1080/00420980410001675788.

75. Tödtling, F., Trippl, M. (2005). One size fits all? Towards a differentiated regional innovation policy approach. Research Policy, 34, 1203-1219. doi: 10.1016/j.respol.2005.01.018.

76. Tödtling, F., Skokan, K., Höglinger, Ch., Rumpel, P., Grillitsch, M. (2013). Innovation and knowledge sourcing of modern sectors in old industrial regions: comparing software firms in Moravia-Silesia and Upper Austria. European Urban and Regional Studies, 20 (2), 188-205. doi: 10.1177/0969776411428498.

77. Trippl, M., Otto, A. (2009). How to turn the fate of old industrial areas: A comparison of cluster-based renewal processes in Styria and the Saarland // Environment and Planning A, 41(5), 1217-1233. doi:10.1068/a4129.

78. Trippl, M., Grillitsch, M., and Isaksen, A. (2017). Exogenous sources of regional industrial change. Attraction and absorption of non-local knowledge for new path development. Progress in Human Geography. Online published: April 3, 2017. doi: 10.1177/0309132517700982.

79. Uskova T.V., Lukin E.V., Mel'nikov A.E., Leonidova E.G. (2017). Industrial development issues in the economy of the old industrial regions of Russia. Economic and Social Changes: Facts, Trends, Forecast, 10 (4). 62-77. [In Russian]. doi: 10.15838/esc/2017.4.52.3. 
80. Vanthillo, T., and Verhetsel, A. (2012). Paradigm change in regional policy: Towards smart specialisation? Lessons from Flanders (Belgium). Belgeo [Online], 1-2, published online: December 04 2012. Retrieved from: http://belgeo.revues.org/7083. Accessed 25 June 2018. [In Ukrainian]. doi: 10.4000/belgeo.7083.

81. Vishnevsky, V., Aleksandrov, I., Polovyan, A. (2011). Scenarios of the old industrial regions' development: selecting the methodology. Environment, Development and Sustainability, 13(1), 65-78. doi: 10.1007/s10668-010-9248-6.

82. Vyshnevsky, V.P., Dementiev, V.V. (2011). Industrial policy for Ukraine: Theoretical aspects. Economic Herald of the Donbas, № 4 (26), 5-20.

83. Zhalylo, Ya. (2017, June, 9). Donbass in search of a new model: six starting positions for the strategy of the future. Retrieved from: https://dt.ua/macrolevel/donbas-u-poshuku-novoyi-modeli-shist-vihidnihpoziciy-dlya-strategiyi-maybutnogo-245055_html. Accessed 25 June 2018. [In Ukrainian].

84. Zhalylo, Ya. (2018, June, 22). On the principles of modern policy of regional development. Mirror of the week, No. 1199-1200. Retrieved from: https://dt.ua/macrolevel/pro-principi-suchasnoyi-politiki-regionalnogorozvitku-281358_html. Accessed 25 June 2018. [In Ukrainian].

85. Zhalylo, Ya., Snihova, O. (2012). The easing of dependence of the old industrial regions in Ukraine on foreign economic factors as a strategic guide for structural policy. Strategic Priorities, 1 (22), 85-91. 